\title{
Interaction of Calix[4]arene and Aliphatic Amines: A Combined NMR, Spectrophotometric and Conductimetric Investigation
}

\author{
Francine F. Nachtigall ${ }^{* a}$, Márcio Lazzarotto ${ }^{a}$ and Faruk Nome ${ }^{b}$ \\ ${ }^{a}$ Departamento de Química, Universidade Estadual de Ponta Grossa, Praça Santos Andrade, s/n, 84010-270, \\ Ponta Grossa - PR, Brazil \\ ${ }^{b}$ Departamento de Química, Universidade Federal de Santa Catarina, CP 476, 88049-970, Florianópolis - SC, Brazil
}

\begin{abstract}
As constantes relacionadas ao equilíbrio entre calix[4]areno e aminas alifáticas em acetonitrila foram medidas por métodos condutivimétrico e espectrométrico e as estruturas dos sais estudadas por espectroscopia de RMN. Em concentrações próximas a $10^{-4} \mathrm{~mol} \mathrm{~L}^{-1}$ predominam os íons livres, enquanto que a $10^{-2} \mathrm{~mol} \mathrm{~L}^{-1}$ aumenta a proporção de pares iônicos. Os valores das constantes para as reações ácido-base permitem avaliar o valor de pKa do calix[4]areno em acetonitrila, igual a 16,6 unidades de $\mathrm{pKa}$. A análise do conjunto de dados está de acordo com a proposta de complexos com o íon amônio em posição exo-calix.
\end{abstract}

The constants related to the equilibria between calix[4] arene and aliphatic amines in acetonitrile were measured by conductimetric and spectrophotometric methods, and the structures of the salts studied by NMR spectroscopy. In concentrations about $10^{-4} \mathrm{~mol} \mathrm{~L}^{-1}$, free ions are at higher proportion, whereas at $10^{-2} \mathrm{~mol} \mathrm{~L}^{-1}$ there is an increase of ion-pairs proportion. The values of the constants found for acid-base reactions allow an evaluation of the value of $\mathrm{pKa}$ for calix[4]arene in acetonitrile as $16.6 \mathrm{pKa}$ units. The analysis of data agrees with a proposal of exo-calix ammonium ion.

Keywords: calixarenes, supramolecular chemistry, interactions of amines

\section{Introduction}

Calixarenes are molecular receptors having a cavity defined by benzene rings and an acidic hydroxylic moiety, able to form complexes with metal ions, anions and neutral molecules. ${ }^{1}$ In acetonitrile, calixarenes react with amines via proton transfer forming salts, that, as proposed by Gutsche, would exist as an equilibrium between exo and endo-calix complexes, in the same manner that calixarenes interact with soft metal cations and fullerenes, ${ }^{2}$ even at low concentrations, such as that used in spectrophotometric titrations. ${ }^{3,4}$

In solid state, ${ }^{5}$ the exo-calix structure of the salt formed by calix[4]arene and piperidine does not show interactions between ammonium ion and the calixarene cavity, and the interaction between ions occurs only through one hydrogen bond between $\mathrm{N}^{+}-\mathrm{H}$ and $\mathrm{O}^{-}$of calix[4]arene. Coulombic interactions have a major role for structures of ammoniumcalixarene salts carrying acid groups. ${ }^{6}$

*e-mail: mlazzaro@uepg.br
De Namor $e$ e $a l^{7,8}$ studying the reactions involving $p$ tert-butylcalix [n]arenes $(\mathrm{n}=6,8)$ and amines in nitrobenzene and benzonitrile, observed that the salts formed exist as an equilibrium between free ions and ion pairs, and determined the values of proton transfer and association equilibrium constants. In these solvents, the formation of free ions was not detected when $p$-tert-butylcalix[4]arene was employed, but it was not determined whether the cause would be an exclusive ion pairing or the lack of proton transfer. A review by De Namor et al. ${ }^{9}$ includes a compilation of the results described in the literature.

In this paper, we report the results obtained for the equilibrium constants of the system aliphatic amines and calix[4]arene, in acetonitrile, which allow the evaluation of the role of the cavity and phenolic oxygens without the interference of groups on para position. The substituents on para position prevent the solvation and a guest immersed in the cavity to suffer interactions with external molecules. In the case of bare calix[4]arene (1), the real balance between $\mathrm{N}^{+}-\mathrm{H}----\pi$ and $\mathrm{N}^{+}-\mathrm{H}_{-}^{--} \mathrm{O}^{-}$may be evaluated. Obviously, the coulombic attraction between $\mathrm{N}+$ and $\mathrm{O}$ 
must be the strongest force present, but the sum of the interactions among $\mathrm{N}^{+} \mathrm{H}$ and the convergent aromatic rings could allow the competition between endo and exo forms of complexes. The absence of the groups in para position, in confront with $p$-tert-butylcalix[4]arene allows faster equilibria between the forms and the exchange of solvent and ammonium cations.

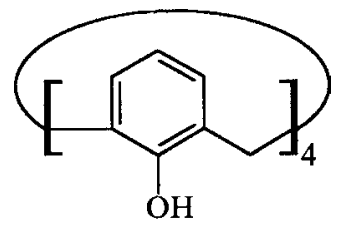

(1)

Scheme 1.

\section{Experimental}

\section{Materials and instrumentation}

Calix[4]arene was prepared as previously described. ${ }^{10}$ Amines (Aldrich) were distilled and dried over molecular sieves, except for piperazine, used without purification. Piperidine (Aldrich) was newly opened and dried over molecular sieves.

Titrations were carried out in acetonitrile (Carlo Erba) in thermostated cells $(298 \pm 0.1 \mathrm{~K})$ and followed spectrophotometrically in a HP 8452-A diode array spectrophotometer and the NMR experiments were carried on Bruker 200 at $298 \mathrm{~K}$.

\section{Results and Discussion}

The spectrophotometric titrations afforded plots of absorbance at $310 \mathrm{~nm} v s$. concentration of amine present after several additions to a solution calix[4]arene and clearly indicate a 1:1 stoichiometry, which is also confirmed by the Job plot for calix[4]arene-piperazine (Figure 1).

As indicated by conductimetric data, discussed below, at the concentration used for the spectrophotometric titrations $\left(10^{-4} \mathrm{~mol} \mathrm{~L}^{-1}\right)$, the equilibrium between calixarene and amine can be assumed as a pure acid-basic reaction, with resulting species as free ions, differently from the exclusive ion pair formation proposed by Gutsche. ${ }^{3}$

$$
\text { calix } \mathrm{OH}+\mathrm{NR}_{3} \stackrel{\mathrm{Kp}}{\rightleftharpoons} \text { calix }^{-}+\mathrm{HNR}_{3}^{+}
$$

Thus, the equilibrium constant, $\mathrm{Kp}$, is defined by Equation 1.

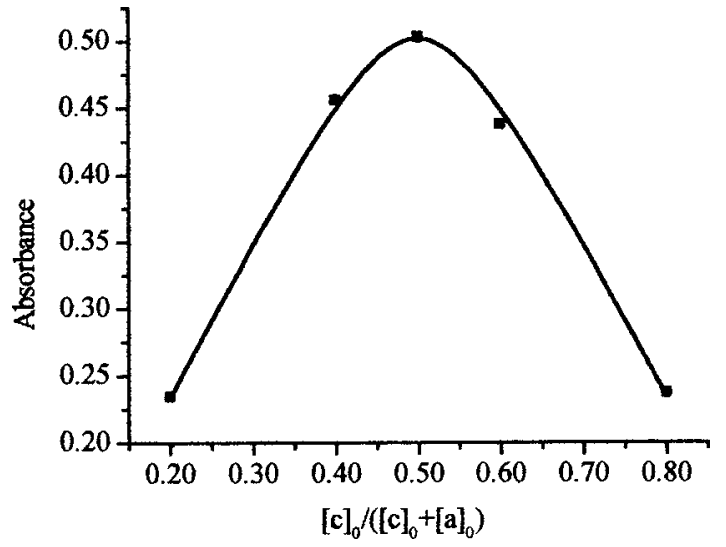

Figure 1. Job's plot for calix[4] arene-piperazine from UV spectra varying the proportion of the reagents and [calix $]+[$ amine $]=3.0 \mathrm{x}$ $10^{-4} \mathrm{~mol} \mathrm{~L}^{-1}$ (constant for all measures). The solid line shows the expected values of absorbance for a 1:1 stoichiometry

$$
K p=\frac{\left[c^{-}\right]\left[a^{+}\right]}{[c][a]}
$$

where $\left[\mathrm{c}^{-}\right],\left[\mathrm{a}^{+}\right],[\mathrm{c}]$ and $[\mathrm{a}]$ are the concentrations of calix[4]arene monoanion, ammonium cation, calix[4]arene and amine present, respectively. Writing the concentrations as functions of $\left[\mathrm{c}^{-}\right]$and the total concentrations of calixarene and amine, $[\mathrm{c}]_{0}$ and $[\mathrm{a}]_{0}$, we may redefine the above equation as:

$$
(1-1 / K p)\left[c^{-}\right]^{2}-\left([c]_{0}+[a]_{0}\left[c^{-}\right]+[c]_{0}[a]_{0}=0\right.
$$

The Lambert-Beer law allows to relate the above equation to the measured absorbances at $310 \mathrm{~nm}$.

$$
\Delta A=\varepsilon\left(\frac{[c]_{0}+[a]_{0}-\sqrt{\left([c]_{0}+[a]_{0}\right)^{2}-4[c]_{0}[a]_{0}(1-1 / K p)}}{2(1-1 / K p)}\right)
$$

The values of $\mathrm{Kp}$ and the molar absortivity of phenolate $(\varepsilon)$ were obtained from non-linear regression, as seen below for the plot of the data of hexylamine (Figure 2). The values of equilibrium constants are listed in the Table 1.

The differences of $\mathrm{Kp}$ values are related with the basicity order of the amines in the solvent utilized. In fact, Equation 4 shows the relation between $\mathrm{Kp}$ and the acidity constants of calixarene, $\mathrm{K}_{\mathrm{DC}}$, and ammonium cation, $\mathrm{K}_{\mathrm{DA}} \cdot{ }^{11}$ Thus, a plot of Kp vs. $\mathrm{K}_{\mathrm{DA}}^{-1}$ gives as angular coefficient an estimate of $\mathrm{K}_{\mathrm{DC}}$ value, that in this case is $2.5 \times 10^{-17} \mathrm{~mol} \mathrm{~L}^{-1}$, meaning a $\mathrm{pK}_{a}$ for calix[4] arene as 16.6 units in MeCN.

$K p=\frac{K_{D C}}{K_{D A}}$

This is the first pKa evaluation of calixarene in $\mathrm{MeCN}$, 


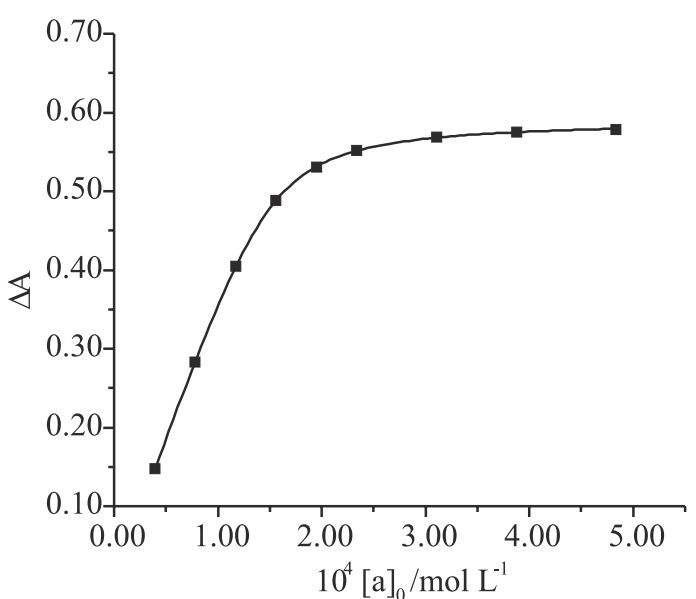

Figure 2. Plot of absorbance at $310 \mathrm{~nm}$ vs. amine concentration $\left([a]_{0}\right)$ from the spectrophtometric measurements of the titration of calix[4]arene with hexylamine in $\mathrm{MeCN}$, at $298 \mathrm{~K}$. The solid line describes the plot of the equation 3 with the values of molar absortivity, equal to $3954 \mathrm{~mol}^{-1} \mathrm{~L}$ and equilibrium constant for the proton transfer reaction, $\mathrm{Kp}$, equal to 18

Table 1. Kp values obtained for calix[4]arene and amines titrations in $\mathrm{MeCN}$

\begin{tabular}{lccc}
\hline Amine & $\mathrm{Kp}$ & $\log \mathrm{Kp}$ & $\mathrm{pKa}^{a}$ \\
\hline Hexylamine & 18 & 1.26 & $(18.26)^{b}$ \\
iso-propylamine & 15 & 1.18 & \\
tert-butylamine & 10 & 1.00 & 18.14 \\
Piperazine & 32 & 1.51 & \\
Morfoline & 0.5 & -0.29 & 16.61 \\
Piperidine & 204 & 2.31 & 18.92 \\
Diethylamine & 139 & 2.14 & 18.75 \\
Triethylamine & 48 & 1.68 & 18.46 \\
\hline
\end{tabular}

$a$. pKa values of the respective ammonium cations from the equilibrium equations: $\mathrm{HN}^{+} \mathrm{R}_{3} \rightleftharpoons \mathrm{NR}_{3}+\mathrm{H}^{+}$, determined in $\mathrm{MeCN}$ and water, at a concentration of $10^{-3} \mathrm{~mol} \mathrm{~L}^{-1}$.

$b$. value from $n$-butylamine.

which for phenol is 26.6. ${ }^{11}$ This difference of ten pKa units reflects the stabilization of the conjugated base by intramolecular hydrogen bonds, that acquires special importance in an aprotic solvent with poor solvating power of anions, as acetonitrile. In benzonitrile, De Namor and co-workers ${ }^{7}$ had determined potentiometricaly the $\mathrm{pKa}_{1}$ values for $p$-tert-butylcalix[n]arenes $(\mathrm{n}=6,8)$ as 17.02 and 17.42 units, respectively. Other measurements in non aqueous solvents were carried by Shinkai and co-workers ${ }^{12}$ for $p$-tert-butylcalix[n]arenes who found, for $\mathrm{n}=4$, an apparent pKa of 4.11. It seems that with the change of solvent for acetonitrile, the calixarene remains in the same range of acidity, when compared with ammonium ions, confirming a more acidic behavior of calixarenes in relation to the corresponding phenols,,$^{13}$ despite the change in solvent properties.
While in spectrophotometric determinations free ions prevail, at concentration used for NMR spectra, the ammonium-phenolate complexes can be detected. The chemical shift values of aliphatic protons of amines protonated by trifluoracetic acid (TFA) or calix[4]arene are listed in Table 2.

Table 2. Chemical shifts values - $\delta$ (ppm) - of the amine hydrogens in the absence and in the presence of TFA or calix[4]arene in $\mathrm{d}_{3} \mathrm{MeCN}$

\begin{tabular}{llccc}
\hline Amine & Hydrogen & \multicolumn{3}{c}{$\delta(\mathrm{ppm})$ value in the } \\
& & none & TFA & calix[4] \\
\hline n-Hexylamine & $\alpha$-CH & 2.57 & 2.91 & 2.93 \\
iso-Propylamine & $\mathbf{C H}$ & 3.00 & 3.45 & 3.45 \\
& $\mathbf{C H}_{3}$ & 0.99 & 1.27 & 1.29 \\
tert-Butylamine & $\mathrm{CH}_{3}$ & 1.07 & 1.35 & 1.39 \\
Piperazine & $\mathrm{CH}_{2}$ & 2.67 & 2.94 & 2.95 \\
Diethylamine & $\mathrm{CH}_{2}$ & 2.56 & 2.99 & 3.01 \\
& $\mathrm{CH}_{3}$ & 1.02 & 1.24 & 1.23 \\
\hline
\end{tabular}

As expected, the protonation of the amine shifts its signals to lower field. TFA is $10^{5}$ times $(\mathrm{pKa}=11 \mathrm{in} \mathrm{MeCN}$ ) more acidic than calix[4]arene, affording complete proton transfer to amine, and in the case of calixarene there are neutral amines present in $c a$. $10 \%$ of excess. Even though, it is observed that their protons are shifted to an even lower field in the presence of calixarene than in the presence of TFA. This demonstrates the complexation of ammonium ions by coulombic attraction and/or hydrogen bonding to the calixarene phenolate.

The absence of shielding effect on the amine aliphatic chain is a clear indication that no intracavity inclusion is taking place.

The conductimetric data allow the determination of the association constats $(\mathrm{Ka})$ between ammonium cations and calixarene phenolate anion. The addition of amine in the calix [4] arene solution $\left([\mathrm{c}]_{\mathrm{o}}=1.0 \times 10^{-3} \mathrm{~mol} \mathrm{~L}^{-1}\right)$ initially increases the conductivity by salt formation, until 1:1 molar ratio of calixarene : amine, when the conductivity values arrive to a plateau. Figure 3 shows the titration curve for piperazine, and the plots for hexylamine, isopropylamine, tert-butylamine, piperidine, diethylamine and trietylamine have the same shape.

In the initial part of the plot there is an excess of calixarene, and the concentration of salt may be considered as the concentration of added amine. Thus, the equilibrium between ion pairs and free ions could be evaluated using the Ostwald dilution law:

$\frac{1}{\Lambda_{\mathrm{m}}}=\frac{1}{\Lambda_{0}}+\frac{\mathrm{Ka}}{\Lambda_{0}^{2}} \mathrm{C} \Lambda_{\mathrm{m}}$ 


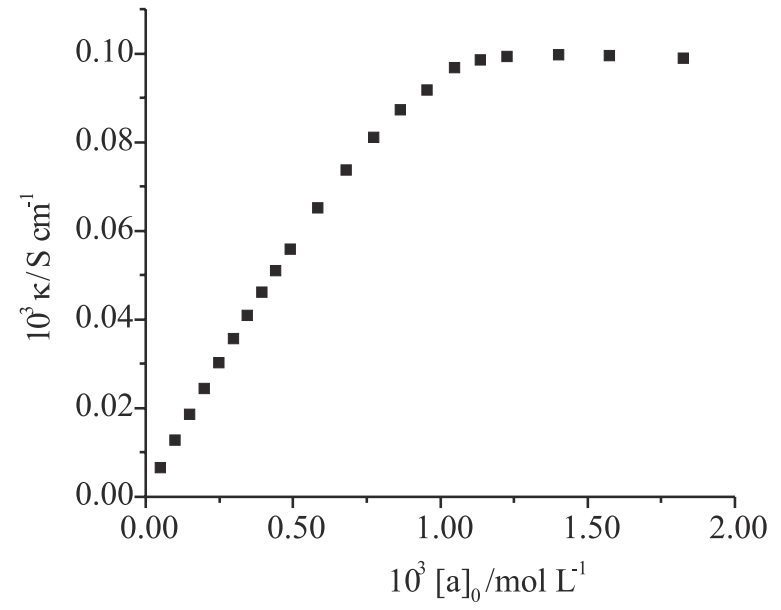

Figure 3. Conductivity values of solutions containing calix[4]arene $10^{-3} \mathrm{~mol} \mathrm{~L}^{-1}$ vs. overall concentration of piperazine $[\mathrm{a}]_{0}$, in acetonitrile at $298 \mathrm{~K}$

where $\Lambda_{\mathrm{m}}$ is the molar conductivity and $\mathrm{C}$ is the salt concentration.

The plots of $1 / \Lambda_{\mathrm{m}}$ versus $\mathrm{C} \Lambda_{\mathrm{m}}$ allow the determination of molar conductivity for infinite dilution $\left(\Lambda_{0}\right)$ from the intercept with absciss axis and the association constant comes from the combination of angular and linear coefficients. Figure 4 shows the data treatment according to Equation 5 for the titration of calix[4]arene with hexylamine. Plots of iso-propylamine, tert-butylamine, piperazine, piperidine, diethylamine and triethylamine have the same shape ( $r>0.99$ for all amines), and the determined Ka and $\Lambda_{0}$ values are reported in Table 3 .

The conductimetric data show that there is a substantial dissociation of the amine/ calix ion-pair, formed by the initial proton transfer. This sharply contrasts with the behavior found by De Namor for $p$-tert-butylcalix[4]arene

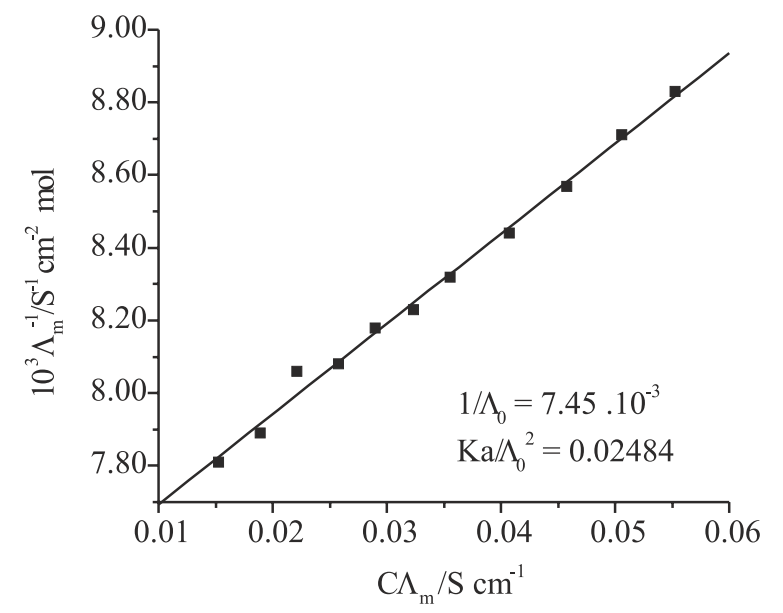

Figure 4. Plot of $1 / \Lambda_{\mathrm{m}}$ vs. $\mathrm{C} \Lambda_{\mathrm{m}}$ of the conductimetric titration of calix[4]arene with hexylamine, in acetonitrile, at $298 \mathrm{~K}$
Table 3. Molar conductivities to infinite dilution $-\Lambda_{0}\left(\mathrm{~S} \mathrm{~cm}^{-2} \mathrm{~mol}\right)$ - and association constant - $\mathrm{Ka}\left(\mathrm{mol} \mathrm{L}^{-1}\right)$ - for calix[4]arene amine salts

\begin{tabular}{lcc}
\hline Amine & $\Lambda_{0}$ & $\mathrm{Ka}$ \\
\hline n-Hexylamine & 130 & 444 \\
iso-Propylamine & 175 & 700 \\
tert-Butylamine & 166 & 864 \\
Piperazine & 144 & 384 \\
Piperidine & 133 & 331 \\
Diethylamine & 135 & 333 \\
Triethylamine & 125 & 149 \\
\hline
\end{tabular}

in nitrobenzene and can be explained by the higher ion solvating power of acetonitrile. In fact, the $\mathrm{E}_{\mathrm{T}}{ }^{\mathrm{N}}$ values for acetonitrile, benzonitrile and nitrobenzene are, respectively, $0.460,0.333$ and $0.324 .{ }^{14}$

The Ka values show a substantial increase going from tertiary to secondary and from these to primary amines. This is in agreement with the increase in the number of hydrogen bonding interactions in ammonium ions, although the magnitude of the $\Delta \Delta \mathrm{G}$ is less than expected for addition of a full hydrogen bond.

Using the Ka values, determined by conductimetry, it is possible evaluate the proportion of associated ions at spectrophotometrical titrations conditions $\left([\text { calix }]_{0}=1.50\right.$ x $10^{-4} \mathrm{~mol} \mathrm{~L}^{-1}$ ), by the equation:

$\left[c^{-} a^{+}\right]=\frac{2[c]_{0}+1 / K a-\sqrt{\left(2[c]_{0}+1 / K a\right)^{2}-4[c]_{0}^{2}}}{2}$

where $\left[\mathrm{c}^{-} \mathrm{a}^{+}\right]$is the ion pair concentration and $[\mathrm{c}]_{0}$ is the overall calixarene concentration in solution.

The calculated proportions of associated ions are $6 \%$ for hexylamine, $9 \%$ for iso-propylamine, $10 \%$ for tertbutylamine, $5 \%$ for piperazine, piperidine and diethylamine and $2 \%$ for triethylamine, showing the predominance of free ions in solution, allowing to consider only the process of proton transfer for spectrophotometrical titrations and to evaluate $\mathrm{Kp}$. As expected, the quality of the adjustment increased with the decrease in the proportion of ion pairs, an indirect indication of the contribution of the association process for the overall equilibrium.

So, the whole data allow the definition of the overall reaction of calix[4]arene and amines as a two-step process.

calixOH $+\mathrm{NR}_{3} \stackrel{\mathrm{Kp}}{\rightleftharpoons}$ calixO $^{-}+\mathrm{HNR}_{3}^{+} \quad($ step 1$)$
calixOH
$\mathrm{HNR}_{3}^{+} \stackrel{\mathrm{Ka}}{\rightleftharpoons}$ calixO $^{-}---\mathrm{HNR}_{3}^{+} \quad($ step 2$)$ 
The first step, defined by $\mathrm{Kp}$ predominates at low concentrations, while at high concentrations the second species becomes detectable, and is responsible for the extra deshielding effect on ammonium protons observed in NMR spectra of amine-calixarene solutions.

The structure of the complexes is, thus, proposed as exo-calix, different from that endo-calix found by Gutsche for $p$-allylcalix[4]arene. The main force in the complexation is coulombic attraction by the opposite poles, which can be strengthened by an additional hydrogen bond in an exo mode of binding (Figure 5), as formed in the solid state.
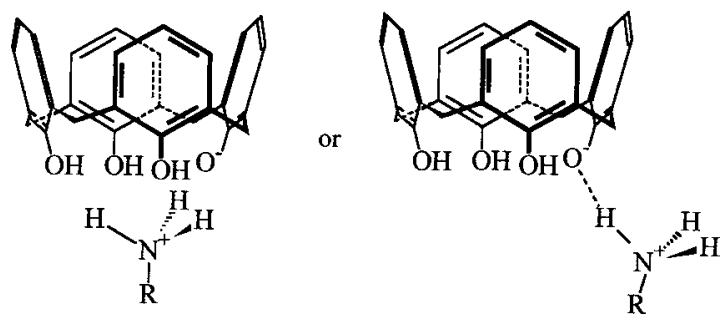

Figure 5 . Proposed structure for the calix[4]arene amine complex $1: 1$

\section{Acknowledgements}

This investigation was supported by PADCT, CNPq and CAPES.

\section{References}

1. Gutsche, C. D.; Calixarenes Revisited-Monographs in Supramolecular Chemistry: The Royal Society of Chemistry; Cambridge, 1998; Böhmer, V.; Angew. Chem. Int. Ed. Engl. 1995, 34, 713; Pochini, A.; Ungaro, R. In Comprehensive Supramolecular Chemistry; Vögtle, F, ed.; Elsevier Science: Oxford, 1996, vol. 2; Lazzarotto, M.; Nachtigall, F. F.; Nome, F.; J. Braz. Chem. Soc. 2001, 12, 255.
2. Shinkai, S.; Ikeda, A.; Pure Appl. Chem. 1999 , 71, 275.

3. Gutsche, C. D.; Iqbal, M.; Alam, I.; J. Am. Chem. Soc. 1987, 109, 4314.

4. Gutsche, C. D.; Bauer, L.; J. Am. Chem. Soc. 1985, 107, 6063.

5. Nachtigall, F. F.; Vencato, I.; Lazzarotto, M.; Nome, F.; Acta Cryst. C54 1998, 1007.

6. Leverd, P. C.; Berthault, P.; Lance, M.; Nierlich, M.; Eur. J. Org. Chem. 2000, 133.

7. De Namor, A. F. D.; Pardo, M. T.; Tanaka, D. A.; Velarde, F. J. S.; García J. C. G.; Cabaleiro, M. C.; Al-Rawl , J. M. A.; J. Chem. Soc. Faraday Trans. 1993, 89, 2727.

8. De Namor, A. F. D.; Wang, J.; Orellana, J. G.; Velarde, F. J. S.; Tanaka, D. A. P.; J. Incl. Phenom. Mol. Recogn. Chem. 1994, 19, 371.

9. De Namor A. F. D.; Cleverley, R. M.; Zapata-Ormachea, M. L.; Chem. Rev. 1998, 98, 2495.

10. Gutsche, C. D.; Levine, J.; Sujeeth, P.; J. Org. Chem. 1985, 50, 5802.

11. Izutsu, K. In Acid-base Dissociation Constants in Dipolar Aprotic Solvents, Chemical Data Series n. 35; IUPAC: Oxford, 1990.

12. Araki, K.; Iwamoto, K.; Shinkai, S.; Matsuda, T.; Bull. Chem. Soc. Jpn. 1990, 63, 3480.

13. Grootenhuis, P. D.; Kollman, P. A.; Groenen, L. C.; Reinhoudt, D. N.; Van Hummel, G. J.; Ugozzoli, F.; Andreetti, G. D.; J. Am. Chem. Soc. 1990, 112, 4165.

14. Reichardt, C. In Solvents and Solvent Effects in Organic Chemistry, $2^{\text {nd }}$ ed.; VHC Verlagsgesellschaft: Weinheim, 1988.

Received: August 1, 2000

Published on the web: March 26, 2002 